Nobuko Gerth

"Between Two Worlds" Hans Gerth 


\section{Jahrbuch Soziologie-Geschichte}


Nobuko Gerth

\section{"Between Two Worlds" Hans Gerth}

Eine Biografie 1908-1978

Springer Fachmedien Wiesbaden GmbH 2002 


\section{Jahrbuch für Soziologiegeschichte}

\section{Herausgegeben von}

Carsten Klingemann

Michael Neumann

Karl-Siegbert Rehberg

Ilja Srubar

Redaktion: Prof. Dr. Carsten Klingemann, Fachbereich Sozialwissenschaften, Universität Osnabrück, Seminarstr. 33, 49069 Osnabrück

Beirat: David Frisby (Glasgow), Hans Joas (Berlin), Dirk Kaesler (Marburg), Horst Kern (Göttingen), M. Rainer Lepsius (Weinheim), Carlo Mongardini (Rom), Paul Neurath (Wien), Sven Papcke (Münster), Michael Pollak † (Paris), Otthein Rammstedt (Bielefeld), Günther Roth (New York), Kurt H. Wolff (Newton, Mass.)

Gedruckt auf säurefreiem und alterungsbeständigem Papier.

\section{ISBN 978-3-8100-3282-9 ISBN 978-3-663-09396-1 (eBook)}

DOI 10.1007/978-3-663-09396-1

(C) 2002 by Springer Fachmedien Wiesbaden

Ursprünglich erschienen bei Verlag Leske + Budrich, Opladen 2002

Das Werk einschließlich aller seiner Teile ist urheberrechtlich geschützt. Jede Verwertung außerhalb der engen Grenzen des Urheberrechtsgesetzes ist ohne Zustimmung des Verlages unzulässig und strafbar. Das gilt insbesondere für Vervielfältigungen, Übersetzungen, Mikroverfilmungen und die Einspeicherung und Verarbeitung in elektronischen Systemen. 


\section{Table of Contents}

Preface

Chapter 1

Family and Childhood.

Chapter 2

University Days

Chapter 3

In Berlin as a Journalist (1934-1937)

Chapter 4

Escape (Fall 1937)

63

Chapter 5

Settling down in the New World (1938 - 1939)

Chapter 6

New Experiences and New Friends:

Relationships with Robert K. Merton and with Edward A. Shils

Chapter 7

University of Wisconsin Part I (1940 - 1953) ......................................... 95

Appointment as Acting Assistant Professor .............................................. 95

During World War II: 1942 - 1945 .................................................... 97

Immediate Postwar Period ..................................................................... 101

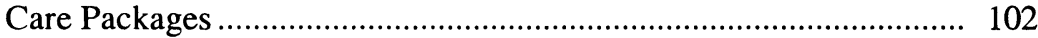

Sixty-day Mission to Germany....................................................... 108

Unsuccessful effort to leave Wisconsin ............................................. 112

Hedwig Ide Gerth ..................................................................... 114 
Chapter 8

University of Wisconsin Part II (1954-1971) ........................................ 121

Brandeis and Columbia Universities (1954) ........................................ 121

Germany (1954/1955) on a Fulbright Grant.......................................... 123

University of California, Berkeley (1957) ........................................... 125

Remarriage and the Automobile Accident ........................................... 125

Alienation in the Department ............................................................ 127

Move to Roxbury .......................................................................... 130

Fulbright Grant to Japan (1962-1964) ............................................... 132

Johann Wolfgang Goethe University (Frankfurt University),

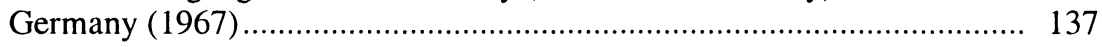

City University of New York (1970) ................................................ 138

End of career at the University of Wisconsin (1971) .............................. 140

\section{Chapter 9}

Three Who Influenced Gerth's Career: Becker - Mills - Martindale ......... 145

Howard Paul Becker (1899 - 1960) .................................................... 145

C. Wright Mills $(1916$ - 1962) ........................................................... 151

Don Martindale (1915 - 1985) ............................................................. 158

Becker, Gerth, Mills, Martindale ....................................................... 164

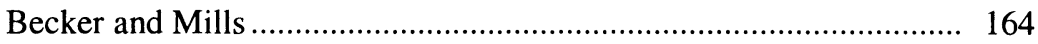

Becker and Martindale: ................................................................. 166

Gerth, Mills, Martindale ............................................................ 168

Chapter 10

Intellectual Accomplishments - Part I Hans Gerth................................. 171

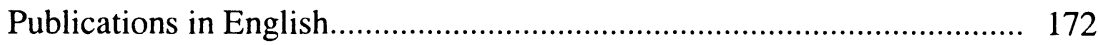

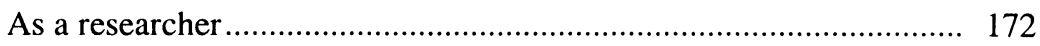

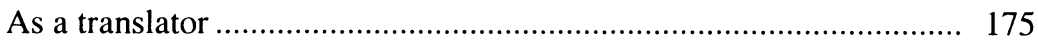

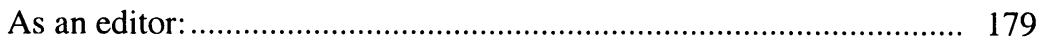

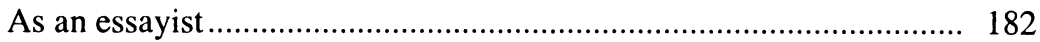

Publications in German:................................................................... 183

(1) ,Moderne Psychologie".......................................................... 183

(2) Kapitalismus und Agrarverfassung......................................... 184

(3) An essay written as an introduction to a planned German translation of C. Wright Mills' White Collar................................ 184

(4) „Friedrich Buchholz: Auch Ein Anfang der Soziologie” (Friedrich Buchholz: Also an Early Sociologist). 
(5) „Zur Soziologie der Intelligenz”

(On the Sociology of the Intelligentsia) ................................... 186

(6) „Zur Soziologie der Denkformen"

(On the Sociology of Thoughtways) ........................................ 186

Chapter 11

Intellectual Accomplishments (Part II) Collaboration ........................... 187

With C. Wright Mills .............................................................................. 187

„A Marx for the Managers.” ........................................................ 187

Max Weber's „Class, Status, Party.” (Translation) ............................. 188

From Max Weber: Essays in Sociology (Translation)........................ 189

Character and Social Structure ....................................................... 194

With Don Martindale ............................................................................ 201

„The Work of Art in the Epoch of Mechanical Reproduction“........... 201

Max Weber's Sociology of Religions ........................................... 202

Chapter 12

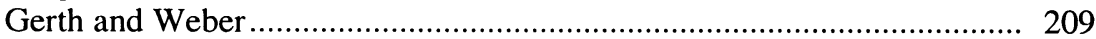

Chapter 13

Life as a Refugee Scholar .................................................................. 219

Chapter 14

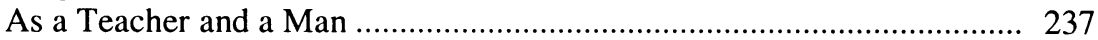

Chapter 15

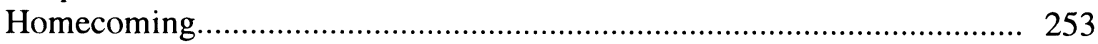

Chapter 16

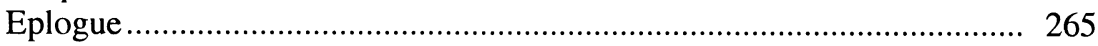

\section{Appendix}

List of Student Days' Friends ............................................................. 267

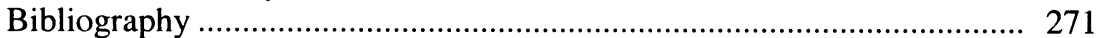

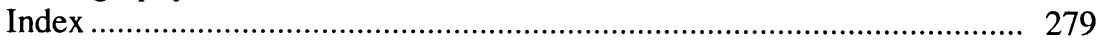




\section{Preface}

After Hans Gerth died in December 1978, I found myself among piles of papers. The amount was considerable, not because he was a ,careful archivist“ as some assumed, but because he simply could not part with any paper with writing on it. Besides his own typed scripts and notes, there were off-prints given to him, papers written by his students, many newspaper clippings, and letters dating back to the end of 1937.

My first task was to look for and collect his essay manuscripts still unknown to the American public. Shortly after Gerth's death, Don Martindale, our life-long friend and a former student of Gerth, encouraged me to publish a volume of Gerth' essays. By going through the piles, I found quite a few essays, even one he wrote as early as 1930 as a student at the London School of Economics. I am sure he had no idea that such an essay had survived among his piles of papers. I edited and typed many of his draft essays; flew to New York to work together on the final edited version with Joe Bensmann and Art Vidich; and co-published it through the Greenwood Press, for which Martindale was an outside consultant.

I then began to sift through Gerth's correspondence files. The correspondence was kept more or less in chronological order. However, the papers were loosely placed into folders and not fastened. As Gerth made several moves in those long years, the folders and papers were jumbled. Missing or torn pages were inevitable, not to mention missing letters. Another problem was that people in those days often did not write the date, especially the year. To arrange them into their chronological order proved to be quite a chore. At times, it was like solving a puzzle, guessing dates from the letter's contents.

There were quite a few people whose correspondence spanned his lifetime, and there were others with whom he had a very intense exchange of letters for only a certain period of time. About 300 letters between C. Wright Mills and Gerth were kept separately from the rest in two thick folders. These letters were crucial to the portrait of Mills that I was asked to write for the Journal of Sociology of Nihon University. The revised version in English ap- 
peared in the International Journal of Politics, Culture and Society. In the present book I again turned to these letters for the chapter on Gerth's relationship to Mills. Copies of these letters were later given to the Mills' estate.

Since his return to Germany, Gerth wrote some personal letters reminiscing on his past. Clearly, memories should not be taken as facts, for one remembers what one wants to remember in the way one wants to remember. Yet, I used these letters also as source material, because they were helpful in locating different events and revealing Gerth's sentiments.

The letters, when taken together, reflect Gerth's life history as a refugee scholar. They date back to the time of his arrival in the United States until his death in Germany. They shed light on his relationship to his friends and acquaintances and their shared concerns. They trace unique events and experiences of his life against the social and personal background of the changing times. Because of this, I quote them as a primary source.

Some interesting old notes written by Gerth exist among his papers. One such note is his description of the Nazi Journalist School that I quote in this book. For a man who escaped with almost nothing within hours of a Gestapo interview, a surprising amount of old documents, including his student days' notes, are among his papers. They were perhaps kept in Germany somewhere and shipped over to the States at a later time. He also left a few pages of his childhood memories, on which I relied.

Besides the papers and letters, I found important information in the Gerth file at the Sociology Department of the University of Wisconsin-Madison. I also obtained declassified files on Gerth from the Federal Bureau of Investigation of the U.S. Government. They have provided important materials for the book.

Books, articles, Ph.D. dissertations and a Master's thesis have been written about Gerth and the circumstances under which some of his works appeared. As I read them, I noted some facts were incorrectly written or interpreted, which in turn led to erroneous conclusions. Had more complete data been available at the time, I feel the interpretations would have been different. I wrote this book to place the record on Gerth in a more correct perspective.

Hans Gerth was one of the many Germans whose life was suddenly interrupted by the Nazis and who had to leave his native land. From all accounts, it is clear Gerth was to pursue his career as a scholar in Germany had it not been for the Nazis. I hope this personal biography of one such refugee sociologist will be of interest to those who would like to reflect on the history of sociology in the United States and in Germany. I should add, though, that those who expect to find an intellectual biography with a critical evaluation of Gerth's ideas will be disappointed. It was not my intent to digest and analyze the many notes he left on Max Weber, Karl Mannheim, and various -isms, but rather to present a detailed personal picture of the contributions and the personal sacrifices of an émigré scholar. I believe when documents of more refugee scholars are made available and researched, we will be able to gain a 
clearer picture of the life and contributions of refugee scholars as a whole. For this reason, I am turning over all Gerth's papers in my possession, including those used as source material for this book, to the Deutsches Exilarchiv of the Deutsche Bibliothek in Frankfurt am Main. The Sozialwissenschaftliches Archiv of Konstanz University houses copies of some of Gerth's notes of his student days, his articles written as a journalist, and his correspondence with Karl Mannheim.

It has been over twenty years since Hans Gerth died. The biographical work I originally started to write for his children and grandchildren as Gerth had wanted in his later years expanded to a larger project as I searched for material. It was, as many projects are, a much more time consuming activity than I had anticipated. Many of his friends and acquaintances who might have enjoyed knowing more about him have passed away in the meantime, and I regret that I did not work more intensely to complete the work sooner.

Some remarks on the footnotes are in order. As far as German documents are concerned, only the unpublished materials, such as personal letters, are reproduced in German in the footnote. In the case of published German material, only its translation appears in the text. When footnotes refer to letters, the word ,letter" is omitted and only the correspondents' names are mentioned as to and from. The letters Gerth wrote but for whatever reasons not mailed or remained in draft form are indicated as unmailed or draft respectively.

While working on this project, I was helped by my friends, acquaintances, and family in various ways. I would like to thank Robert K. Merton, Professor Emeritus at Columbia University, for his encouragement and for mailing me the letters of Gerth's early days in the United States. They were an invaluable source for Gerth's early experiences in the New World. I thank Prof. John M. Spalek of the University at Albany of State University of New York, who kindly mailed me many books that are hard to obtain in Germany to facilitate my research. Edith Martindale gave me Don Martindale's book of verses and writings, The Academic Life with her Introduction, and copies of Gerth's letters kept at the University of Minnesota Archives. All these furnished some very helpful information, and I want to thank her for her kindness. Thanks go to Arthur Vidich, Professor Emeritus at the New School for Social Research, for sending me from time to time relevant information on Gerth, including some letters from the Emergency Committee in Aid of Displaced German Scholars (the Notgemeinschaft Deutscher Wissenschaftler im Ausland) that Dr. Christian Fleck of the University of Graz found while researching in the New York Public Library archive. Thanks also go to Professor H. Ishikawa of Seijo University in Tokyo for giving me a copy of the Foreword to the Expanded Edition of Hustlers, Beats, and Others by Ned Polsky. Dr. Wilfried Dreyer called my attention to and provided me with copies of a part of the book, Rudolf Heberle, by Rainer Waßner, and Max Horkheimer's Gesammelte Schriften Band 12. I thank him for his generous help. The book, Intellektuelle im Aufbruch by Dr.Reinhard Blomert of Humboldt 
University, Berlin, contains much useful information on Gerth's Heidelberg days, and I thank the author for mailing me the book.

I thank the Department of Sociology, University of Wisconsin-Madison, for making the Gerth file available and for the use of their facilities while I was in Madison. Professor Joe Elder was especially helpful in making it possible for me to use the University Archives of the Memorial Library.

Special thanks go to Professor James Russell of Eastern Connecticut State University. He read the first draft of the manuscript, offered detailed comments and gave me many valuable hints. He helped locate necessary information on some books and tirelessly encouraged me towards its publication. I thank Professor Uta Gerhardt of Heidelberg University for reading my manuscript in the draft stage. She continuously encouraged and advised me regarding its publication. I also thank Dr. Franz Mößner for his help in reading old handwritten German documents.

I wish to thank Professor Gert König, Gerth's nephew, who supplied me background documentation on the Gerth family. I thank Dr. Thomas Logan, the husband of Anne Gerth Logan, for reading and painstakingly correcting grammatical and stylistic errors in my first draft. Also, I want to thank Anne Logan for her help in ascertaining the procedure for obtaining documents from the Federal Bureau of Investigation. Dr. Richard Gerth, my son, did a careful reading of the final draft. He offered invaluable help in correcting, editing, and producing the manuscript in its final publishable form.

Last, but not least, my sincere appreciation goes to Professor Ilja Srubar of Erlangen University for his help in negotiating with the publisher for publication of this book. Without the assistance of all these people, this book would not have been possible. It goes without saying, however, that the responsibility for the contents of the book lies with the author alone.

Glashütten/Ts. June 2001

Nobuko Gerth 